\title{
Compassion, Power and Organization
}

\author{
AV Simpson ${ }^{1}$, SR Clegg $^{* 2}$, D Freeder $^{3}$ \\ UTS Business School, Centre for Management and Organization Studies (CMOS), University \\ of Technology, Sydney (UTS), Australia
}

*Visiting Professor, Nova School of Business and Economics, Lisbon, Portugal

\footnotetext{
1 ace.simpson@uts.edu.au

2 stewart.clegg@uts.edu.au

${ }^{3}$ daphne.freeder@uts.edu.au
} 


\begin{abstract}
In this paper we analyse the significance of compassion as an emotion in its relationship to various manifestations of power within the organizational context. We critique those theories of compassion that assume that compassion in organizational contexts is motivated only by a noble intent. The paper draws on a study of organizational responses to the flood that devastated the City of Brisbane Australia on the morning of January 11, 2011. We use Clegg's (1989) research framework of 'circuits of power' to provide a triple focus on interpersonal, organizational and societal uses of power together with Etzioni's (1961) model of coercive, instrumental and normative organizational power. We present our findings in a framework constructed by overlapping Clegg (1989) and Etzioni’s (1961) frameworks. The unique contribution of this paper is to provide a conceptualization of organizational compassion enmeshed with various modes of power exercised in and by organizations.
\end{abstract}

Keywords: compassion, emotion, power, organization 


\section{Introduction}

Disasters trigger emotions of pain, hurt, sorrow and grief. They also pose major problems for organizations. As well as existential and social consequences of disaster there are organizational effects. Adversity can act as a naturally occurring breaching experiment, revealing the tacit and underlying assumptions, and informal rules of organizational life (Garfinkel, 1967). The ways that organizations respond to disaster reveals orientations to work and deep structures of power relations stripped of the veneer of normalcy. Normally, power relations in organizations are represented as presenting a rational face in a public space in which emotionality is kept under strict control (Weber, 1978). The myth of the purely rational mechanical organization, devoid of emotionality, was challenged by Flam (1990b) and Albrow (1992, p. 314). Subsequent research has addressed both negative and positive organizational emotions.

Negative work experiences can lead to negative emotions (Cordes \& Dougherty, 1993; Maslach, 2003) including: experiences such as interpersonal conflicts and sexual harassment (Gutek \& Morasch, 1982; Tangri, Burt, \& Johnson, 1982); bullying and violence (Barling, 1996; Rhodes, Pullen, Vickers, Clegg, \& Pitsis, 2010); toxic work relations, stress and burnout (Frost \& Robinson, 1999); bereavement (Bento, 1994; Eyetsemitan, 1998); unfair dismissal and redundancy (E Galdón-Sánchez \& Güell, 2003); workplace accidents (Shannon et al., 1996); errors and equipment failures (Ammerman, 1998); and terrorist attacks (Beunza $\&$ Stark, 2005). In addition, there is a growing literature on the effects of the 'dark side' of organizations (Clegg, e Cunha, \& Rego, 2012; Clegg, 2006; Clegg, Cunha, \& Rego, 2012).

By contrast, Positive Organization Scholarship (POS) stresses positive organizational relations, policies, and practices (Caza \& Caza, 2008). A major focus of POS research has been on alleviating suffering through organized compassion (Lilius, Kanov, Dutton, Worline, 
\& Maitlis, 2012; Rynes, Bartunek, Dutton, \& Margolis, 2012). In addition, there are longstanding research traditions inquiring into emotions that are seen as positive for organizations, such as employee commitment (Biggart, 1990; Roe, Solinger, \& Van Olffen, 2008). In this literature Roe et al (2008), for instance, make connections between power relations and positive emotions, as do Van Kleef et al. (2008) and Nussbaum (2003), who follow Nietzsche $(1998,2002)$ in arguing that the social expression of compassion is not only an emotion but also a power relation. From their perspective power is inevitably inherent in relations involving compassion: for instance, compassion may be offered but not accepted; claimed but not offered, and so on (Bamford, 2007; Cartwright, 1984, 1988; Frazer, 2006; Frost et al., 2006).

Compassion, considered as something that will be offered or not from the one to the other on the basis of socially constructed premises, entails seeing it as, potentially, a technique of power relations in organizations. Compassion, involving someone being perceived in need by someone in a position to provide or withhold help, while it will always be contextually specific has general parameters of power relations. Choice is always present. The compassion giver exercises choice because they can act in a way that they construe as compassionate or not and the subject of that act of compassion also makes a choice in terms of how it is received. They can choose to recognise that action positively as compassionate, or they might choose to see it as negative, perhaps because they deem it patronizing.

In this article we are particularly concerned with the ways in which the expression of emotional suffering and compassion are articulated within an organizational context, and their connections with organizational power. We explore the growing interest in organizational compassion and critique this literature for the absence of considerations of power. The floods of January 2011 in Brisbane, Australia and the divergence in 
organizational responses to the flood crisis offer a naturally occurring experimental research context within which to situate inquiry; hence, we use the occurrence of the flood to frame our data collection and provide the content for our analysis. The extraordinary occurrence provides a window through which to see or make explicit the ongoing organizational capabilities for compassion embedded in organizational routines. The project of 'making visible' what is generally 'invisible' reveals the power dynamics that are embedded within all organizational compassion relations.

Theoretically, we adapt Etzioni's (1961) model of organizational power and relate it to Clegg’s (1989) ‘circuits of power' framework. Consequently, our research findings are organized in terms of a three by three model of organizational power relations. In terms of the organizational flood support provided to employees by their organizations Etzioni’s (1961) three categories of organizational power are translated as neglect, ambiguity, and care, categorisations that are then aligned to Clegg's (1989) power framework of episodic coworker relations, dispositional organizational practices, and the macro facilitative societal or political context. We then analyse 'obligatory passage points' where the circuits of power interconnect, providing insights about how compassion relations reveal systemic organizational power. The implications of our findings are framed in an explicit model of power relations specifically configured to the articulation of compassion in organizations.

\section{Emotion, Power and Compassion in Management and Organization Studies}

\section{Emotion}

Significantly, in the face of an overwhelmingly rationalist tradition, Flam (1990a) argued that emotions are woven into organizational life. She questioned economic, decision-making and organizational theory perspectives stressing rational choice theory and instead proposed a 
three-dimensional perspective on individual actions and choice involving blended rationalnormative-emotional components. Flam (1990b) argues that organizations that have specific goals, such as charities helping those in need, political parties expressing solidarity, professional organizations that build trust, or business organizations achieving profit, are often infused with formalized emotional commitments. Charities, foundations, and state departments, for example, are ostensibly created to nurture and regulate otherwise arbitrary and inconsistent applications of compassion for those in need. Similarly, trade and professional associations are formed to nurture solidarity within their membership group and garner the trust of the public. Consequently, the objective of constructing and sustaining specific emotions becomes entwined with organizational goals.

Fineman (2000) similarly argues that emotions are woven into the roles, decisions, culture, meanings, production, and politics that constitute organizational life. He is critical of viewpoints found within psychoanalytic theory that see unconscious fears, shame, and guilt interfering with rational cognitive processes. Fineman responds by questioning the privileging of rationality over emotionality. More importantly, he questions the emotionality/rationality distinction as a false premise. It is impossible to separate one from the other - boundaries between them are always blurred and ambiguous. Fineman is critical of the psychological determinism of traditional approaches. Emotions are shaped not only by psychological causes but also by cultural and social influence and are saturated with power relations.

\section{Power}

Scholars have argued that, conventionally, power has been ignored, trivialized, restricted, or overlooked within organizational analysis and discourse (Hardy \& Clegg, 2006), despite the foundations of organization in power (Clegg, 2009). In conventional organization theory 
power is often misconceived as limited to a title or position and the resources associated with rank that enable force to be wielded coercively to make others do what they would not otherwise do (Dahl, 1957 is the classic statement; see the critique in Gordon, 2008). By contrast, post-Foucauldian scholars describe power as inscribed in social relations and the struggle for meaning (Clegg, 1989; Haugaard, 2012b). Power can be enacted by making or delaying decisions and actions, establishing or blurring certainty, tolerating or addressing evil, bestowing or withholding privilege, and claiming or violating human rights (Clegg, Courpasson, \& Phillips, 2006). In a similar vein Knights and Roberts (1982) argue that we should conceive of organizational power in terms of the quality of relationships. It is because power permeates all social relations that it is central to organizational discourse and analysis (Clegg \& Haugaard, 2009). In fact, Clegg, Courpasson and Phillips (2006, pp. 2, 3) describe power as "the central concept in the social sciences" and "the core of organizational achievement".

Power has been seen as a singular essentially contested concept (Lukes, 2004). Other scholars, such as Etzioni (1961) and Clegg (1989) work with differentiated conceptions of power. Etzioni (1961) provides a typology of three types of organizational power: coercive, instrumental and normative. Coercive power is conceived as the potential for inflicting force and restricting privileges. Instrumental power is based upon remuneration through the control of material assets allocated as wages and other benefits. Normative power rests upon the manipulation, allocation, restriction and distribution of rewards of symbolic prestige and esteem. Etzioni proposes that there are three congruent zones of employee commitment responses that align with these modes of power: in ideal type terms coercive power leads to alienation, normative power to moral involvement, and instrumental power to a calculative commitment (Clegg \& Dunkerley, 1980). Clegg's (1998) 'circuits of power' framework portrays power as flowing through interacting circuits: the episodic circuit focuses on micro 
episodes such as interpersonal dealings while the dispositional circuit is concerned with meso organizational norms, policies, and routines and the facilitative circuit addresses the macro socio-regulatory structure and cultural context. The circuits (re)constitute each other through interactions at transitory 'obligatory passage points', in which the taken-for-granted rules and norms constituting practices are negotiated and fixed.From these positions, which are more nuanced than the essentialist view of Lukes, power relations may be regarded as multifaceted, encompassing not only power over but also the more positive power to and power with (Haugaard, 2012a). Each mode of power has distinct compassion relations associated with it.

When compassionate aid is institutionalised at the organizational level, considerations of power and domination become significant. The returns to a compassionate organization in terms of building 'power to' can be great, including instilling within employees positive emotions such as hope and trust (Dutton, Lilius, \& Kanov, 2007), a greater sense of personal identity or self (Frost et al., 2006), as well as a deepened level of commitment to co-workers and the organization (Dutton et al., 2007). Frost et al (2006) warn, however, of the potential for 'power over' relations predominating when compassion relations are motivated by instrumental goals for increased productivity and improved public relations. Roberts (1984) and Knights and Roberts (1982) observe that when managers project an appearance of care in others' interests, as a tactic to fulfil organizational interests, the yield is usually only a temporary advantage. Management's intentions are revealed not just through words but also through behaviours. Attempts to gain control through sham relationships ultimately meet with resistance either through physical or emotional distancing.

\section{Compassion}

Scholars define compassion in organizations as a threefold relational process of collectively 
noticing another is suffering, empathising with their pain, and responding in some manner (Dutton, Glynn, \& Spreitzer, 2006; Dutton, Worline, Frost, \& Lilius, 2006; Frost et al., 2006; Kanov et al., 2004). Noticing entails developing awareness of another's emotional state possibly through openness to their emotional cues and knowledge of significant life events. Empathy relates to feeling another's pain, while responding involves an effort to alleviate the other's suffering condition. The definition is limited because it does not account for compassion as a social process, thus neglecting the experiences of the receiver and the inherent power relations. The receiver may experience manifestations of concern leading to actions of assessment and response as more or less positive or negative, more or less caring or manipulative: hence, compassion entails power relations. Organizational compassion is evident in assessments of and responses to perceived potential suffering. Such expressions (or non-expressions) frame compassionate issues and non-issues (Clegg \& van Iterson, 2009; van Iterson \& Clegg, 2008).

Compassionate organizational responses to employee suffering are of increasing interest as theory has become more open to the acknowledgment of emotional dispositions other than those that merely express means-ends rationality. For instance, research indicates that compassionate leadership during a tragic event facilitates healing and growth amongst employees (Lilius, Worline, Dutton, Kanov, \& Maitlis, 2011). Conversely, organizational neglect can invoke emotions of anger and resentment (Dutton, Frost, Worline, Lilius, \& Kanov, 2002). Organizational compassion has been seen to build positive emotions such as pride, trust, and motivation, giving strength to values of dignity, respect, and concern for others, as well as cultivating relational skills (Dutton et al., 2007). Studies further indicate that organizational compassion strengthens individual identity and organizational identification (Frost et al., 2006). Additionally, it enhances the commitment of employees towards co-workers and the organization (Dutton et al., 2007). 
The outcomes of organizational compassion relations vary. The negative results of organizational compassion have been described as compassion work (Frost et al., 2006), compassion labour (Ashforth \& Humphreys, 1993; Morris \& Feldman, 1996), and compassion fatigue (Figley, 1995, 2002a, 2002b). Compassion work involves people endeavouring to overcome their natural dislike for a particular colleague at work by attempting to generate feelings of compassion for the person (Frost et al., 2006). Compassion labour commonly occurs in professions such as counselling, social work, and nursing, where being seen to respond with compassion to others' pain is regarded as a constitutive element in the professional pose (Ashforth \& Humphreys, 1993; Morris \& Feldman, 1996). Particularly when there are no positive results, compassion work and compassion labour can lead to compassion fatigue, a state of being mentally, emotionally and physically exhausted (Figley, 1995, 2002a, 2002b). Those exercising compassion in contexts of emotional labour in which they are not genuinely engaged (Hochschild, 1983) will not be able to sustain the emotion without detriment to themselves and to those they serve. Organizational toxic handlers, the people in organizations who absorb pain and distress, because they are vulnerable to the emotional hurt of fellow workers, register the effects of compassion fatigue (Frost, 2003; Hatfield, Cacioppo, \& Rapson, 1993).

Givers and receivers in compassion relations make mutual assessments of each other that provide a sense of the validity and worthiness of the actions of others. Legitimacy assessments by a receiver of compassion focus on the power motives of the person offering compassionate support. Responding involves giving, accepting, or refusing compassion support. Those aware of compassion dynamics can manipulate the kind of compassion responding that is provided to boost their own philanthropic social standing or to impose intimacy, indebtedness or dependency (Clark, 1987, 1997; Schmitt \& Clark, 2006) through the norm of reciprocity (Gouldner, 1960). Additionally, a receiver can feel patronized and 
belittled by offers of compassion that highlight their deficiencies and problems and so reject them. Conversely, a receiver may accept a giver's assistance to enhance their own social standing by ensuring that public displays of gratitude highlight the recipient's link with influential supporters.

We investigate the connection between organization, compassion, and power through an empirical study of organizational responses of support or non-support during the floods that devastated the City of Brisbane Australia in January 2011, which caused the Central Business District (CBD) to be evacuated as well as the temporary closure of many organizations.

\section{Research context and method}

We employ qualitative methodologies to capture a view of organizational compassion within a social relational context. On the morning of January 11, 2011, when excess capacity was released from the Wivenhoe Dam upstream from the Queensland State Capital of Brisbane (necessitated by extreme weather conditions), water began flooding downstream. By 2:30 pm the Brisbane River had broken its banks and people were evacuated from 2,100 streets within the CBD and surrounding areas.

Using social networks that were already established in areas affected by the floods, we contacted potential participants whose work had been disrupted by the floods. Data from a snowball sample of 25 people from 18 organizations was collected. The organizations included a cafeteria, a restaurant, the headquarters of two travel major agencies, the state headquarters of a leading bank, two universities, a non-governmental organization, two government departments, two information technology companies, a real estate company and an office supplies business. All of these organizations were located in the flood-affected areas of central Brisbane and received orders to evacuate their premises on January 11, 2011. The 
accounts of all 25 participants from all 18 organizations are represented in this study, accounts that varied in the richness of information. Interviews were conducted in cafes, libraries and other neutral spaces, lasting between twenty minutes to an hour. The semistructured interviews were recorded digitally with consent and with ethical assurances of individual and organizational anonymity. Completed interviews, 12 hours in total, were transcribed in full and imported into NVivo 9, for qualitative analyses. The software was used to highlight and categorise "nodes" comprising key themes and subthemes. The unit of analysis for coding was the utterance rather than the respondent; consequently more utterances are coded than actual number of respondents.

Coding was a laborious process involving the three authors in approximately 220 hours of consideration, discussion and decision. First, descriptive coding was used to identify recurring themes in the interviewees discourse. These categories were refined as progressed coding (Strauss \& Corbin, 1997). These dimensions were collapsed and categorized using an analytical framework that expanded Etzioni (1961) and Clegg's (1989) models by conceiving of compassion as power relations.

Initially the types of power relations were categorised according to organizational patterns of power and related degrees of commitment, using Etzioni's (1961) terms. The pairs were conceptualized as perceived organizational negligence with regard to the disaster leading to alienation rather than commitment, while perceived organizational instrumentalism about the costs of the disaster was associated with a calculative commitment, whereas perceived organizationally compassionate responses were associated with normative commitment. Employees expressed systematic attitudes towards their employing organizations that varied respectively with anger, cynicism, or gratitude towards their organization. Clegg's (1989) circuits of power model was then used to organize responses under three additional 
categories: was the power relation largely episodic (conceptualized in terms of interpersonal co-worker relations), dispositional (conceptualized in terms of organizational norms, routines, policies, and practices), or facilitative (conceptualized in terms of socio-regulatory structure, and cultural environment or context)? Analytic attention focused on Clegg's 'obligatory passage points' to observe power shifts in the unfolding of the floods as the three circuits interacted and reconstituted each other.

Application of two formal theoretical frameworks (Clegg, 1989; Etzioni, 1961) together with grounded analysis resulted in an inductive construction of "social science concepts using concepts of social actors as the foundations for analytic induction" (Rynes \& Gephart Jr, 2004, p. 457), from which our theoretical framework emerged (Table 1). The descriptive codes constitute the specific details of frequency occurrence. The evidence is consolidated into different emergent themes, grouped within a combination of Etzioni (1961) and Clegg's (1989) frameworks (Langley, 1999). Etzioni's three modes of organizational power are represented in three columns denoting organizational flood responses categorised as neglect, ambiguity (including instrumental support), and compassion. Clegg's circuits of compassion are represented in levels of episodic, dispositional and facilitative power relations. At the bottom of the table Etzioni's modes of employee commitment responses delineate various types of anger, mixed feelings, and positive emotions such as commitment and gratitude.

Table 1 About Here

The main themes that emerged from our interviews are presented below. Organizational examples are used to demonstrate one or more of the organizational compassion capabilities 
exhibited in assessment, decision-making, and responding. The instances are valuable because they relate to the flood as an extreme event in which power relations became more visible and they also provide a window on routine organizational values, policies and procedures. Organizations more or less assisted or neglected their employees through the power relations they used to deal with the traumas of the floods.

\section{Themes in Episodic Relations of Compassion And Power}

In Clegg's (1989) framework the episodic circuit represents irregular micro-level agential relations. Here the focus is on episodic exercises of power in co-worker relations in terms of the ways that individuals address feelings, communicate, and offer support and resistance in day-to-day interrelations. In the context of this study, organizational responses of support for employees during the Brisbane floods involved a combination of factors such as anticipating concerns, communicating compassionately, showing concern for the other's safety, and arranging to provide emotional, physical, and financial support during a period of uncertainty. Within this frame we are concerned with compassion enacted as power over in making, delaying, or withholding decisions or actions that provide support. As anticipated by Etzioni's (1961) theory of organizational power we found three heuristic categories of organizational compassion responses: neglect, ambivalence, and care with three different employee commitment outcomes of anger, cynicism, and gratitude.

Neglect

Neglect is a form of non-decision with several characteristics. One form of neglect was to hold employees back at work for as long as possible, even after evacuation of the city. Another form was expressed in terms of unreasonable demands on employees to come to work despite the floods, or the failure to communicate concern for, or update, employees on 
when they might be able to return to work. Additionally, and more overtly, other organizations didn't continue salary payments for the days that employees were unable to work, making an active choice not to assist their employees. These negligent responses and non-responses generally led to employee feelings of disappointment, anger and emotional distancing from the organization.

Ironically, one example of such neglect was an international NGO, a non-profit organization that offers counselling support services, in which the supervisor kept employees at work long after evacuations commenced in the CBD. Employees were increasingly anxious that they might not be able to get home as roads and public transport lines were becoming flooded and inaccessible. When they enquired if they would be paid for their work that day if they left early, their supervisor would not give a clear answer. When employees heard that one of the train lines had stopped operating, they just left work. Through the week these employees had to phone in to find out when they were expected back at work and they were not informed if they would be paid for the days they were unable to attend. When work resumed a few days later, those who were absent during the floods were penalised for their absence. The employees learned subsequently that they would be given three days of paid leave. Any additional absence was to be debited from their annual leave irrespective of whether it was flood related. Employees were angry at this unfair treatment - particularly from an organization that has as its mission caring for people.

\section{Ambiguity}

A second type of response was ambiguity; wherein, the organization made token gestures of concern. Here 'care' was slow to get started but assumed greater significance later. Employees had the impression that this 'care' was not expressed out of concern for employees. Rather, its expression was a way of managing the negative impacts of having not 
initially provided support. Organizations managing in this way were seen, for example, to be fulfilling a legal obligation only in order to avoid court cases, maintaining relationships with a valuable workforce in short supply, or managing public relations. The emotional response of employees to such token measures of support was mixed. In cases where people focused on neglect, it elicited self-preservation responses. In other cases, where people focused on care, pro-social motivation was elicited; mostly, however, the response was indifference. While appreciating the token effort it did not engender much in the way of member commitment to the organization.

An example of ambiguous relations was an international travel organization where employees were forced to stay at work to back up computers and transfer operations to divisions in other cities and countries after the official evacuation of Brisbane. Employee anxiety quickly turned into anger at the organization for making them stay. People worried about their families and properties as well as the diminishing prospects of getting home that evening because public transport was closing down. Once they were given permission to leave, however, they did receive follow up phone calls from their supervisors to see whether they were making it home safely. These calls were appreciated but the interviewees felt they were made due to legal imperatives. Travel to and from work involves the financial consideration of compensation if a mishap occurs to an employee. The interviewees felt that the organization was more concerned about protecting itself from a legal challenge of employee neglect rather than caring for its members. Employees were not informed if they would be paid for the week they could not work until a week after work resumed, when they were told they would be paid in full. They appreciated this positive gesture but viewed it, once again, as motivated by social pressures from the government, the media, and general public, all of whom were urging support of people during the flood. External coercion, employees' felt, 
had motivated the organization to provide additional support, so as not to be seen in a negative light.

\section{Compassionate care}

The third type of response was one of compassionate care. A key characteristic of such care was speedy communication, which in some cases sought to alleviate employee concern even before it had time to become manifest. Such communication used a variety of media, including verbal communication, email, text messages, the Internet, and open forums. The content of this communication focused on two key areas: the first was that before work commitments employees should make their personal safety and that of their families their number one priority. The second was an assurance that they would be compensated with their usual pay during the period that they could not work due to the flood. In some instances employees were told they should take as much time as they needed before returning to work. Throughout the week of the flood, in another organization employees received enquiries about their wellbeing and need for support as well as updates on the situation at the workplace. Employees of this organization expressed pride in how well their organization supported them through the flood period. They further expressed a desire to reciprocate by working hard for the organization and supporting fellow co-workers. Compassionate organizations also made financial and other gifts to employees affected by the floods and contributed to overall flood relief. They used their power to facilitate adaptation to the floods as a form of positive power.

Organizations that bent their rules and adjusted standard policies to provide support and also provided financial support to help members recover household items that had been lost in the floods were considered by employees to have shown high compassion. As an example, one employee told how, when her manager asked about what she had lost in the flood, she said 
she had been unable to save any of her husband's equipment from the garage, including the lawnmower and power tools. A few days later at a company social evening, the manager publicly gave her $\$ 2000$ worth of hardware store vouchers to replace her husband's work equipment. The employee appreciated that her manager had listened and offered a gift that was directly related to her losses. As she received her voucher and gave her manager a hug of gratitude, he whispered into her ear that the organization would also be transferring a financial gift of $\$ 4000$ dollars into her account.

\section{Themes in Dispositional Relations of Compassion and Power}

The dispositional circuit of our model deals with the ways in which power relations are expressed through local controls, in terms of policies, procedures, rules and informal agreements. These help to structure the dispositions of those entangled in the circuits of power. In analytical terms we might think of these as the plethora of rules that seek to fix meaning and membership in the organization in question. In the compassion context, these official and unofficial rules and socially constructed meanings inform member relations and legitimate or fail to legitimate instances of compassion. Compassionate organizations have in place policies, systems and routines that legitimise collective recognising, feeling and responding to employees' pain (Dutton et al, 2006). These policies, systems and routines reflect and ensure the availability of resources to support the enactment of a culture that supports values of dignity, commitment to others, respect, equality, and importance of members (Frost, 1999).

\section{Philosophy of care}

The most significant finding was the relationship between the measures taken by the organization during the flood and its on-going and normal displays of organizational emotion 
as a caring (or not) employer. Those organizations that had an explicit philosophy and culture of care were quick to communicate with and assure their employees, even anticipating concerns before they arose. Those organizations that did not have such an explicit philosophy were much slower to communicate and more negligent in their responses to employee concerns, in some cases exacerbating anxieties.

Employees often take organization espousals prioritising 'the value of our people' with a grain of salt, as a cliché often heard but rarely seen in practice; however, in those organizations that responded best during the flood, prioritising people over profits was embedded and signified in more than just words. An interviewee employed at a leading Australian bank in which quarterly performance evaluations involved managers being assessed not just in terms of profits but also in terms of how peers and supervisors experience working with them as dependable and respectful human beings, explained that these ways of ranking people over profits involved genuine respect and cooperation that carried over to the crisis. Our findings suggest that crucial to practice of compassion is the explicit adoption of policies and practices that uphold respect for the human dignity of employees. Such policies ensure compassionate support is provided as a mode of organizational routine even when it is apparently not profitable for the organization to do so. Such policies include allowing for bereavement leave, community service participation, work-life balance, and family friendly hours of work. Another key factor supporting the practices of a caring organizational environment is the recruitment and promotion of managers who act as role models through great leadership and compassionate care. Lawrence and Maitlis (2012) suggest that caring organizations show an organizational focus on an 'ethic of care' that is on-going, regardless of whether or not the 'other' is suffering or flourishing, rather than just reacting to specific instances of employees suffering. Such organizations demonstrate a commitment to corporate social responsibility by drawing a link between doing the right thing by employees 
and providing the best support and value to customers and society more generally. Finally, a high organizational capability for expressing compassion was signified through the development of prior contingency planning to support employees in the event of crisis. The organizations that best exemplified such concern had emergency planning in effect as the floods unfolded.

\section{Themes in Facilitative Relations of Compassion and Power}

Stable and taken for granted social relations that generate routine episodes of organizational behaviour can be configured and reconfigured through either dispositional or facilitative circuits of power, especially as exogenous contingencies or events have an impact on established ways of doing and being. In this study, regional and state government interventions and media reports framing organizations and individuals positive compassion capabilities were important exogenous contingencies in the context of the rising floodwaters.

\section{Government}

Six of the respondents said that they were particularly impressed by the state government's efforts during the floods. In particular, they praised the setting up of shelters across the region where people could rest, find blankets, shower, and have access to food and drink. They also lauded the speed with which the state government, local councils, and volunteers worked in restoring infrastructure, such as cleaning up the roads. The army and local contractors as well as the community supported the clean-up effort. Australia's major banks set up mobile ATM machines at shelters with some having representatives on hand to help customers apply for 'hardship' arrangements, allowing customers to put their mortgage and credit card interest repayments on hold for up to three months. 
One respondent, an academic, expressed the view that had the flood been in a less wealthy country, people would not have received the same quick and efficient support. The government provided grants of $\$ 1000$ per person to people from areas without electricity for 48 hours or more and the banks cashed these checks at the shelters. While one interviewee felt these endowments were wasteful examples of the government "throwing money at a problem" another, who had donated to the government flood appeal, was upset that the state government later imposed conditions on the funding allocations. A few interviewees were upset that people who were not in hardship after the floods took advantage of official flood funding.

\section{Community}

The most inspiring story of the Brisbane floods was how armies of volunteers, armed with brooms and buckets, showed up to help with the clean-up effort. The effects of compassionate care were contagious. An interviewee, who had to evacuate her home during the flood was relieved to go home and find it unscathed and, on seeing members of the council, the Australian army, and dozens of volunteers working in the street outside her home, cried with gratitude. Seeing these efforts she and her husband were inspired to volunteer in other people's homes. As she cleaned dishes in a stranger's kitchen and her husband helped in the yard outside, emotions were high: in loss the volunteering of others provided a form of positive emotional contagion in the face of adversity. Overall 14 of the 25 interviewees provided similar accounts of receiving support and in turn volunteering support to others - an outcome that offers corroboration to the ideas of emotional contagion theorists (Barger \& Grandey, 2006; Barsade, 2002; Pugh, 2001).

\section{Discussion}


In this study we have compared citywide flood responses across organizations, the media and community and explored organizational capabilities for compassion, revealing the power dynamics embedded within organizational routines. We analysed Brisbane flood interview data using Etzioni’s (1961) power commitment model along with Clegg's (1989) circuits of power model as a framework. Various modes of organizational power interact within the various circuits constituted by and constituting each other, through what Clegg labels 'obligatory passage points' of transition, in which the taken-for-granted nature of implicit rules and norms are negotiated and fixed. The Brisbane floods provide a window into organizational compassion expressed through supportive or non-supportive responses to employees, providing valuable insight into organizational compassion as a complex social relational process. When particular acts in the episodic circuit of interpersonal relations breached expectations of compassionate behaviour, the interconnectedness of the circuit became particularly vivid. Organizations that had the greatest compassion relations at the episodic level of analysis during the course of the flood had corresponding dispositional practices of compassion embedded within the nature of the organizations policies, systems, culture, and routines.

Were there effects of structural contingency at work, such that the more bureaucratised the organization the better the response? For instance, one might hypothetically expect that 'people-centred' bureaucracies would have more formally compassionate routines inscribed within them, because of the centrality of people processing to their workflow, given the findings of the Aston School (Pugh \& Hickson, 1976). The evidence was contradictory: on the one hand the university represented in the data certainly fitted these expectations; however, the NGO, very much a people-centred and national organization, did not. 
In our study of the Brisbane floods we acknowledge that resource variations across organisations may be a likely explanation for disparities in the types of compassion that were extended or its perceptible absence. The capacity of the university for example to substitute other staff for those that are absent is likely to be much greater than that of the NGO. This raises the question of whether compassionate treatment of employees is inextricably linked to overall organisational resources such as finance, insurance cover or staff numbers. "While compassionate interpersonal acts are rarely large or dramatic, they may become so in the minds of the recipients" (Lilius et al., 2008, p. 213). Very few organizations, would be in a position to gift $\$ 6000$ to an employee after a crisis such as this but nor would they necessarily need to. It is the perceived care that is interpreted and validated by staff and not necessarily the monetary value of how compassion is articulated.

Citing an example from 2011 in Kolkata, in India, where medical staff abandoned their patients in the midst of a fire, Rynes et al (2012) discuss apparent paradoxes in the expression of compassion, such that care and compassion "may emerge where they are least expected and may well be endangered where they are most expected" (Rynes et al., 2012, p. 503). Hence, it would be mistaken to assume that NGOs, whose mission is care, are necessarily 'better' employers. A recent study of 212 international welfare workers discussed a propensity for NGO managers to regard staff's ability to withstand negative emotions as an inherent part of their work role. As a consequence, the results of the study indicated high incidences of mental health issues in stressed NGO staff (Cardozo et al., 2012). While it may be proposed that NGO management perspectives are generally motivated by consideration of the greater public good, in the context of long-term retention of staff and the associated costs of hiring and training new staff this would appear not to be the case. 
Our findings suggest that while the profitability of an organization may be a factor in the provison of support it is not the final determinant. Some organizations that were large in scale and highly profitable provided negligiable support, wheras others that were small in scale (the café) with minimal access to recources provided overwhelming assistance.

Other social factors are also significant, including the social context or facilitative environment. As an example, the findings indicate relationships between the messages conveyed by government efforts at the facilitative level of analysis with the care and compassion expressed at the episodic and dispositional levels. The care organized by government agencies through quick mobilization of resources in the clean-up effort at the facilitative level was linked to individual efforts to volunteer and contribute support to others at the episodic level. At the episodic level, interviewees who received support were in many instances inspired to support others. At the dispositional level, community spirit and volunteering placed pressure on organizations that initially had been slow to respond, pressing them to offer better support to their employees.

The findings of co-constitutive effects of the episodic, dispositional, and facilitative circuits through 'obligatory passage points' can be further analysed in terms of our findings of different employee commitment levels, as theorized by Etzioni (1961). Our findings revealed that neglect made employees become disaffected from the organization, thereby reducing their 'social integration'. As expressed by the interviewees, they would in future be less willing to 'put themselves out' for the organization. Accordingly, we can theorise that the total dispositional power available to such organizations is likely to decrease ${ }^{4}$. At the other end of the spectrum, the various statements by employees who receive care and compassion suggest that this increased their social integration within the organization. Consequently, at

\footnotetext{
${ }^{4} \mathrm{We}$ thank one of the reviewers of this article for this insight.
} 
the dispositional level their subject position constituted as being dependable employees intensified. Systemically this means that the powers available to the organization as a whole increased. Our analysis thereby reveals that organizational care and compassion can increase (positive-sum) or decrease (zero-sum) the total systemic power of the organization (Haugaard, 2012b). In future competition with other organizations these positive-sum organizations should be better able to 'organizationally outflank' other organizations. Conversely, neglect makes organizations less reliable, decreasing 'system integration', which will be damaging.

Timing and the form of organizational compassion were also significant factors. Offers of organizational compassion were variously experienced as positive, negative and ambiguous depending on the timing and form of organizational compassion. Negative power over or zero-sum power was experienced as manipulative, violent, dominating, constraining, antagonistic, destructive, and inhibitive. Positive-sum power to and power with had the effect of being seen as generative, empowering, and facilitative.

Compassionate relations increased employees' integration with the organization, enhancing systematic power for the organization as a whole, with increased employee loyalty/commitment and, crucially, increased symbolic capital accruing to the organization both internally and externally. That this was the case begs the question of whether or not the deployment of compassionate practices may be a subtle form of 'soft domination' (Courpasson, 2000) that is positive (in the Foucauldian sense) in creating more compliant and 'committed' employees. From this perspective, compassion and a rhetoric espousing a 'philosophy of care' would just be disciplinary power with a compassionate face. We do not propose to expand on this aspect of corporate compassion in the context of this paper but 
offer it merely as further evidence of the complex intricacies of compassion as a social relational process entwined with power relations.

\section{Conclusion}

The specific contribution of this analysis is its theorisation of organizational compassion not just as an internal psychological state but also as a political and organizational emotion and therefore as a mode of power relations. Power is neither just positive nor negative-it is both, and often concurrently (Foucault, 1987). We agree with Fineman's (2006a, 2006b) criticism of POS as offering an unduly positive account of emotions such as compassion. Compassion relations are a process rather than just an outcome. We have analysed organizational compassion as a complex on-going social relational process reinforcing power relations. For POS the research could be seen to provide a more nuanced framework for organizing better organizational power relations and compassionate care, with a general result of greater employee commitment. We found that outcomes of power applications were indeterminate and subject to revisions based upon the priorities, relevancies, and connections made retrospectively and prospectively at any given moment. We can see this at the episodic level on those occasions where several interviewees refused to acknowledge the support they received from their organization as compassionate care. Even though these interviewees were grateful for the support received, they saw the assistance as provided in response to coercive pressure from the facilitative environment.

Organizational scholarship on compassion, while it has dealt with extraordinary events (Dutton et al., 2002), has not described how these are connected organizationally to overall power relations. We sampled a range of organizations and variations in compassion relations through our interviews. Theoretically, we have demonstrated the utility of thinking of power in broad terms as both positive and negative and have applied the same approach to 
compassion. In this way we displayed that how compassion is expressed can either produce commitment and increase the overall systemic power of the organization or lessen these. The research demonstrates that compassion in crisis moments reveals power and commitment relations towards employees that are organizationally embedded and more implicit than evident. Compassion is deeply engrained (or absent and ambiguous) in the organizational fabric rather than something that is just a psychological variable. Practically, there are many lessons to be learnt concerning compassion as a mode of power relations.

\section{References}

Albrow, M. (1992). Sine ira et studio - or do organizations have feelings? Organization Studies, 13(3), 313-329.

Ammerman, M. (1998). The root cause analysis handbook: a simplified approach to identifying, correcting, and reporting workplace errors. New York: Productivity Press.

Ashforth, B. E., \& Humphreys, M. (1993). Emotional labor in service roles: The influence of identity. Academy of Management Review, 18(1), 88-115.

Bamford, R. (2007). The virtue of shame: Defending Nietzsche's critique of mitleid. In G. Von Tevenar (Ed.), Nietzsche and ethics (pp. 241-261). Bern, NY: Peter Lang.

Barger, P. B., \& Grandey, A. A. (2006). Service with a smile and encounter satisfaction: Emotional contagion and appraisal mechanisms. Academy of Management Journal, 49(6), 1229-1238.

Barling, J. (1996). The prediction, experience, and consequences of workplace violence. In G. R. VandenBos \& E. Q. Bulatao (Eds.), Violence on the job: Identifying risks and developing solutions (pp. 29-49). Washington: American Psychological Association.

Barsade, S. G. (2002). The ripple effect: Emotional contagion and Its influence on group behavior. Administrative Science Quarterly, 47(4), 644-677.

Bento, R. F. (1994). When the show must go on: Disenfranchised grief in organizations. Journal of Managerial Psychology, 9(6), 35-44.

Beunza, D., \& Stark, D. (2005). Resolving identities: Successive crises in a trading room after 9/11. In N. Foner (Ed.), Wounded city: The social impact of 9/11 (pp. 293-320). New York: Russell Sage Foundation. 
Biggart, N. W. (1990). Charismatic capitalism: Direct selling organizations in America. Chicago: University of Chicago Press.

Cardozo, B. L., Crawford, C. G., Eriksson, C., Zhu, J., Sabin, M., Ager, A., . . Kaiser, R. (2012). Psychological distress, depression, anxiety, and burnout among international humanitarian aid workers: A longitudinal study. PloS One, 7(9), e44948.

Cartwright, D. E. (1984). Kant, Schopenhauer, and Nietzsche on the morality of pity. Journal of the History of Ideas, 45(1), 83-98.

Cartwright, D. E. (1988). Schopenhauer's Compassion and Nietzsche's Pity. In M. Koßler, D. Birnbacher \& H.-G. Ingenkamp (Eds.), Schopenhauer Jahrbuch 69 (pp. 557-567). Frankfurt am Main: A. Lutzeyer.

Caza, B. B., \& Caza, A. (2008). Positive organizational scholarship. Journal of Management Inquiry, 17(1), 21.

Clark, C. (1987). Sympathy biography and sympathy margin. American Journal of Sociology, 93(2), 290-321.

Clark, C. (1997). Misery and company: Sympathy in everyday life. Chicago: University of Chicago Press.

Clegg, S., e Cunha, M. P., \& Rego, A. (2012). The Theory and Practice of Utopia in a Total Institution: The Pineapple Panopticon. Organization Studies, 33(12), 1735-1757.

Clegg, S. R. (1989). Frameworks of power. London: Sage.

Clegg, S. R. (2006). Why is organization theory so ignorant? The neglect of total institutions. Journal of Management Inquiry, 15(4), 426-430.

Clegg, S. R. (2009). The foundations of organization power. Journal of Power, 2(1), 35-64.

Clegg, S. R., Courpasson, D., \& Phillips, N. (2006). Power and organizations. London: Sage.

Clegg, S. R., Cunha, e. M. P., \& Rego, A. (2012). The Evil of Utopia. In C. L. Jurkiewicz (Ed.), Foundations of Organizational Evil (pp. 225-244). Thousand Oaks, CA: Sage.

Clegg, S. R., \& Dunkerley, D. (1980). Organization, class and control. London: Routledge \& Kegan Paul.

Clegg, S. R., \& Haugaard, M. (Eds.). (2009). Sage handbook of power. London: Sage.

Clegg, S. R., \& van Iterson, A. (2009). Dishing the dirt: gossiping in organizations. Culture and Organization, 15(3-4), 275-289.

Cordes, C. L., \& Dougherty, T. W. (1993). A review and an integration of research on job burnout. Academy of Management Review, 18(4), 621-656.

Courpasson, D. (2000). Managerial strategies of domination: Power in soft bureaucracies. Organization Studies, 21(1), 141-161. 
Dahl, R. A. (1957). The concept of power. Behavioral science, 2(3), 201-215.

Dutton, J. E., Frost, P., Worline, M. C., Lilius, J. M., \& Kanov, J. M. (2002). Leading in times of trauma. Harvard Business Review, 80(1), 54-61.

Dutton, J. E., Glynn, M. A., \& Spreitzer, G. M. (2006). Positive organizational scholarship.

In J. Greenhaus \& G. Callanan (Eds.), Encyclopedia of Career Development (pp. 641644). Thousand Oaks: Sage.

Dutton, J. E., Lilius, J. M., \& Kanov, J. M. (2007). The transformative potential of compassion at work. In S. K. Piderit, R. E. Fry \& D. L. Cooperrider (Eds.), Handbook of transformative cooperation: New designs and dynamics (pp. 107-124). Stanford: Stanford University Press.

Dutton, J. E., Worline, M. C., Frost, P. J., \& Lilius, J. (2006). Explaining compassion organizing. Administrative Science Quarterly, 51(1), 59-96.

E Galdón-Sánchez, J., \& Güell, M. (2003). Dismissal conflicts and unemployment. European Economic Review, 47(2), 323-335.

Etzioni, A. (1961). Complex organizations: A sociological reader. New York: Holt, Rinehart and Winston.

Eyetsemitan, F. (1998). Stifled grief in the workplace. Death Studies, 22(5), 469-479.

Figley, C. R. (1995). Compassion fatigue: Coping with secondary traumatic stress disorder in those who treat the traumatized. London: Brunner-Routledge.

Figley, C. R. (2002a). Compassion fatigue: psychotherapists' chronic lack of self care. Journal of Clinical Psychology, 58(11), 1433-1441.

Figley, C. R. (2002b). Treating compassion fatigue. London: Brunner-Routledge.

Fineman, S. (2000). Emotional arenas revisited. In S. Fineman (Ed.), Emotion in organizations (second ed.). London: Sage.

Fineman, S. (2006a). Accentuating the positive? Academy of Management Review, 31(2), 306-308.

Fineman, S. (2006b). On being positive: Concerns and counterpoints. Academy of Management Review, 31(2), 270-291.

Flam, H. (1990a). Emotional Man: I. The emotional man and the problem of collective action. International Sociology, 5(1), 39-56.

Flam, H. (1990b). Emotional Man: II. Corporate actors as emotion-motivated emotion managers. International Sociology, 5(2), 225-234. 
Foucault, M. (1987). The Ethic of Care for the Self as a Practice of Freedom: An Interview with Michel Foucault on January 20, 1984. Philosophy \& social criticism, 12(2-3), $112-131$.

Frazer, M., L. (2006). The compassion of Zarathustra: Nietzsche on sympathy and strength. Review of Politics, 68(1), 49-78.

Frost, P. J. (2003). Toxic emotions at work. Boston: Harvard Business School Press.

Frost, P. J., Dutton, J. E., Maitlis, S., Lilius, J. M., Kanov, J. M., \& Worline, M. C. (2006). Seeing organizations differently: Three lenses on compassion. In S. R. Clegg, C. Hardy, T. B. Lawrence \& W. R. Nord (Eds.), The Sage handbook of organization studies (pp. 843-866). London: Sage.

Frost, P. J., \& Robinson, S. (1999). The toxic handler: organizational hero--and casualty. Harvard Business Review, 77(4), 96-106.

Garfinkel, H. (1967). Studies in ethnomethodology. Cambridge: Polity Press.

Gordon, R. D. (2008). Power in organizational behavior. In S. Clegg \& C. L. Cooper (Eds.), The SAGE handbook of organizational behavior: Macro approaches (Vol. 2, pp. 150161). London: Sage.

Gouldner, A. W. (1960). The norm of reciprocity: A preliminary statement. American sociological review, 25(2), 161-178.

Gutek, B. A., \& Morasch, B. (1982). Sex ratios, sex role spillover, and sexual harassment of women at work. Journal of Social Issues, 38(4), 55-74.

Hardy, C., \& Clegg, S. R. (2006). Some dare call it power. In S. R. Clegg, C. Hardy \& W. R. Nord (Eds.), Handbook of organization studies (2 ed., pp. 754-776). London: Sage.

Hatfield, E., Cacioppo, J. T., \& Rapson, R. L. (1993). Emotional contagion. Current Directions in Psychological Science, 2(3), 96-100.

Haugaard, M. (2012a). Editorial: reflections upon power over, power to, power with, and the four dimensions of power. Journal of Political Power, 5(3), 353-358.

Haugaard, M. (2012b). Rethinking the four dimensions of power: domination and empowerment. Journal of Political Power, 5(1), 33-54.

Hochschild, A. R. (1983). The managed heart: the comercialization of human feeling. Berkley: University of California Press.

Kanov, J. M., Maitlis, S., Worline, M. C., Dutton, J. E., Frost, P. J., \& Lilius, J. M. (2004). Compassion in organizational life. American Behavioral Scientist, 47(6), 808-827.

Knights, D., \& Roberts, J. (1982). The power of organization or the organization of power? Organization Studies, 3(1), 47-63. 
Langley, A. (1999). Strategies for theorizing from process data. Academy of Management Review, 24(4), 691-710.

Lawrence, T., \& Maitlis, S. (2012). Care and possibility: Enacting an ethic of care through narrative practice. Academy of Management Review, 37(4), 641-663.

Lilius, J. M., Kanov, J., Dutton, J. E., Worline, M. C., \& Maitlis, S. (2012). Compassion revealed: What we know about compassion at work (and where we need to know more). In K. S. Cameron \& G. Spreitzer (Eds.), The Oxford Handbook of Positive Organizational Scholarship (pp. 273-287). Oxford: Oxford University Press.

Lilius, J. M., Worline, M. C., Dutton, J. E., Kanov, J. M., \& Maitlis, S. (2011). Understanding compassion capability. Human Relations, 64(7), 873-899.

Lilius, J. M., Worline, M. C., Maitlis, S., Kanov, J. M., Dutton, J. E., \& Frost, P. J. (2008). The contours and consequences of compassion at work. Journal of Organizational Behavior, 29(2), 193-218.

Lukes, S. (2004). Power: A radical view (2nd ed.). New York: Palgrave Macmillan.

Maslach, C. (2003). Job burnout. Current Directions in Psychological Science, 12(5), 189192.

Morris, J. A., \& Feldman, D. C. (1996). The dimensions, antecedents, and consequences of emotional labor. Academy of Management Review, 21(1), 986-1010.

Nietzsche, F. (1998). On the genealogy of morals (D. Smith, Trans.). New York: Oxford University Press.

Nietzsche, F. (2002). Thus spoke Zarathustra (A. Del Caro, Trans.). Cambridge: Cambridge University Press.

Nussbaum, M. C. (2003). Upheavals of thought: The intelligence of emotions. Cambridge: Cambridge University Press.

Pugh, D. S., \& Hickson, D. J. (1976). Organizational structure in its context: The aston programme 1. London: Saxon House.

Pugh, S. D. (2001). Service with a smile: Emotional contagion in the service encounter. Academy of Management Journal, 44(5), 1018-1027.

Rhodes, C., Pullen, A., Vickers, M. H., Clegg, S. R., \& Pitsis, A. (2010). Violence and workplace bullying: What are an organization's ethical responsibilities? Administrative Theory \& Praxis, 32(1), 96-115.

Roberts, J. (1984). The moral character of managment practice. Journal of Management Studies, 21(3), 287-302. 
Roe, R. A., Solinger, O., \& Van Olffen, W. (2008). Shaping organizational commitment. In S. Clegg \& C. L. Cooper (Eds.), The Sage handbook of organizational behavior: Macro approaches (Vol. 2, pp. 130-149). London: Sage.

Rynes, S., Bartunek, J., Dutton, J., \& Margolis, J. (2012). Care and compassion through an organizational lens: Opening up new possibilities. Academy of Management Review, Published online ahead of print.

Rynes, S., \& Gephart Jr, R. (2004). From the editors. Academy of Management Journal, 47(4), 454-462.

Schmitt, C., \& Clark, C. (2006). Sympathy. In J. E. Stets \& J. H. Turner (Eds.), Handbook of the Sociology of Emotions (pp. 467-492). New York: Springer.

Shannon, H. S., Walters, V., Lewchuk, W., Richardson, J., Moran, L. A., Haines, T., \& Verma, D. (1996). Workplace organizational correlates of lost time accident rates in manufacturing. American Journal of Industrial Medicine, 29(3), 258-268.

Strauss, A., \& Corbin, J. (1997). Grounded theory in practice. London: Sage.

Tangri, S. S., Burt, M. R., \& Johnson, L. B. (1982). Sexual harassment at work: Three explanatory models. Journal of Social Issues, 38(4), 33-54.

van Iterson, A., \& Clegg, S. R. (2008). The politics of gossip and denial in interorganizational relations. Human Relations, 61(8), 1117-1137.

van Kleef, G. A., Oveis, C., Van der Lowe, I., LuoKogan, A., Goetz, J., \& Keltner, D. (2008). Power, distress, and compassion. Psychological Science, 19(12), 1315-1322.

Weber, M. (1978). Economy and society: an outline of interpretive sociology. Berkley, CA: University of California Press. 
Table 1: Typology of organizational power/compassion relations during the Brisbane floods.

\begin{tabular}{ccc}
\hline Negative Power Relations & Ambiguous Power Relations & Positive Power Relations \\
(Number of utterances) & (Number of utterances) & (Number of utterances) \\
\hline
\end{tabular}

Episodic organizational relations

- None (17) - Slow/limited communication

(3)

- Quick/frequent communication

(26)

\begin{tabular}{|c|c|c|}
\hline \multicolumn{3}{|c|}{ Communication Quality } \\
\hline - Unreasonable demands (10) & $\begin{array}{l}\text { - Mixed caring/uncaring } \\
\text { messages (2) }\end{array}$ & - Singular caring message (29) \\
\hline \multicolumn{3}{|c|}{ Applying policies through the crisis } \\
\hline $\begin{array}{l}\text { - Rigid bureaucracy not adapted } \\
\text { to context (4) }\end{array}$ & $\begin{array}{l}\text { - "Company policy" } \\
\text { apologetically cited as excuse } \\
\text { for minimal care }(2)\end{array}$ & $\begin{array}{l}\text { - Flexibility in bending } \\
\text { policy/procedures (6) }\end{array}$ \\
\hline
\end{tabular}

Modes of support in crisis

- No pay given (3) • Delayed/limited pay (3) • Assurance of pay (16)

- No support given (5)

- Non-specific rather than specific support (3), part support (1)

- Listening to individual needs (3), gifting (11), counselling

(5), targeted help (22)

- No motive to help displayed

- Motives of guilt (9), social/legal pressures (5)
- Motives of care (11), gratitude on receiving help (4), seeing others helping (4)

\section{Dispositional relations}

Philosophy of care

- Valuing profits \& productivity - Ambiguous priorities (2) (9)

- Organizational control (3) • Limited empowerment (3)

- Rigid work arrangements (6)

- People hired to do a job (2)

- People to work hard \& win commissions, bonuses \& competitions (2)

Work/Life balance

- Overwork with low pay (5) • High work load with high pay

- Unfair pay (9)

- Emphasis on bonuses/rewards

(2)

Support as a mode of organizational routine

- No routine support in crisis (5) - Clever arrangements to avoid responsibility in crises (2)

routine
- Valuing people over profits (31)

- High empowerment, autonomy, respect \& trust (21)

- Flexible work options to suit individual needs (21)

- People hired to fulfil their passions (intrinsic rewards) (2) Emphasis on work/life balance

Fair pay (5)

- Special arrangements to
support employees in crisis(14)


- Close \& caring role models (15)

\begin{tabular}{lll}
\hline & Corporate social responsibility \\
\hline $\begin{array}{l}\text { No concern for community } \\
\text { issues }\end{array}$ & $\begin{array}{c}\text { CSR valuable for public } \\
\text { relations (5) }\end{array}$ & $\begin{array}{c}\text { Strong commitment to } \\
\text { community (CSR) (9) }\end{array}$
\end{tabular}

\section{Facilitative relations}

Media, Politicians, Banks and Government

- Media feeds panic (9)

- Politicians/leaders feed panic

(2)

- Bank owned insurance companies fail to cover flood losses (6)
-Sensationalize story (2)

- Politicians scoring public relations points (1)

- Bank owned insurance companies delay flood loss pay-outs (1)

- Positive media messages about survival, support, recovery (5)

- Politicians/leaders project calm \& care (9)

- Banks provide emergency cash/loans, halt mortgage/credit card repayments, portable ATMs, counselling (15)

- Community volunteers clean, support, provide food (11)

- Government organizes shelters, cash grants (6), food, \& quick clean-up; engages army, police, contractors, \& volunteers (13)

flood claim government $\$ 1000$ grants allocated for victims (3), grants too small \& businesses not included (3)

\section{Commitment responses by employees to organizational power relations}

- Emotional responses of panic (4), anxiety (10), anger (9), distancing (7)
- Cynicism (3), anger (1), appreciation (3), gratitude (2)
- Emotional responses of gratitude (8), bonding (13), feeling valued (4), happiness (2), loyalty (8), peace (4), pride in organization (2) 